\title{
ANALISIS INDIKATOR KETERCAPAIAN NILAI-NILAI KEWIRAUSAHAAN MATA PELAJARAN PRAKARYA DAN KEWIRAUSAHAAN JENJANG PENDIDIKAN MENENGAH
}

\author{
Wahidmurni, Universitas Islam Negeri Maulana Malik Ibrahim Malang \\ wahidmurni@pips.uin-malang.ac.id
}

\begin{abstract}
ABSTRAK
Tujuan penelitian adalah mengungkap kesenjangan rumusan kompetensi sikap, pengetahuan dan ketrampilan dalam silabus mata pelajaran Prakarya dan Kewirausahaan sebagai fenomena dengan naskah indikator ketercapaian nilai-nilai kewirausahaan dan standar proses sebagai kriteria. Desain penelitian Goal Oriented Evalution Model digunakan, dengan menggunakan naskah Kurikulum mata pelajaran Prakarya dan Kewirausahaan di SMA/MA/SMK/MAK Kurikulum 2013 Edisi Revisi 2016 sebagai sumber data penelitian. Analisis data dengan menerapkan langkah analisis yang dikembangkan Youker et al., yakni dengan menetapkan kriteria, standar, pengukuran dan sintesis. Hasil penelitian menunjukkan bahwa nilai-nilai sikap kepribadian dan sikap sosial wirausaha tidak terumuskan dengan baik dalam naskah silabus; rumusan kata kerja kompetensi pengetahuan seluruhnya mengunakan kata kerja memahami padahal sebagian besar menuntut kompetensi kemampuan berpikir tingkat tinggi (menganalisis, mengevaluasi dan mengkreasi); dan sebagian besar rumusan kata kerja kompetensi ketrampilan kurang tepat, karena menggunakan kata kerja ranah pengetahuan. Implikasinya adalah perlu adanya perbaikan rumusan kata kerja kompetensi yang tepat pada naskah kurikulum, karena ini akan berimplikasi pada seluruh aspek pembalajaran.
\end{abstract}

Kata Kunci: Kompetensi Sikap, Kompetensi Pengetahuan, Kompetensi Ketrampilan, Nilai-nilai Kewirausahaan, Pendidikan Kewirausahaan.

\begin{abstract}
This study aimed to reveal the gap in the formulation of attitude, knowledge and skill competencies in the Crafting and Entrepreneurship syllabus as phenomena with the indicators of achievement of entrepreneurial values and process standards as criteria. The research was designed with the Goal Oriented Evalution Model, using the Curriculum of the Crafting and Entrepreneurship subject in SMA/MA /SMK/MAK 2016's Revised Edition of Curriculum 2013 as the data source. The data were analyzed by the analytical steps developed by Youker et al., namely setting criteria, standards, measurements and synthesis. The results showed that the values of entrepreneurial behavioral attitudes and social attitudes were not well formulated in the syllabus; the formulation of verbs of knowledge competencies uses the action verb "to understand" even though most of them require the use of verbs which train
\end{abstract}


the students' High Order Thinking Skills (i.e. to analyze, to evaluate and to create); and most of the formulations of the skills competency verb are inappropriate, because they use the verb of the knowledge domain. The study suggests necessary improvement in the formulation of appropriate competency verbs in the curriculum because it will have implications for all aspects of learning.

Keywords: Attitude Competence, Knowledge Competence, Skill Competence, Entrepreneurship Values, Entrepreneurship Education.

\section{PENDAHULUAN}

Kewirausahaan dianggap sebagai sarana yang sangat penting bagi kemakmuran suatu negara. Hal ini sangat disadari oleh banyak negara tentang pentingnya menginternalisasikan dan membelajarkan pendidikan kewirausahaan bagi warganegaranya. Hasil Seminar Inter-Regional yang diselenggarakan oleh United Nations Educational, Scientific and Cultural Organization (UNESCO) di Thailand pada tahun 2008 telah merekomendasikan pentingnya pendidikan kewirausahaan untuk membekali peserta didik kemampuan untuk berinisiatif, bertanggungjawab, mengambil resiko, kreatif, berinovasi, dan memiliki kemampuan berpikir di luar kotak. Hal ini untuk mengantisipasi dan merespon perubahan masyarakat (UNESCO, 2008). Scott (2015) menyatakan ada kebutuhan kurikulum yang terbuka untuk fokus pada interdisipliner, mengabung belajar secara informal dan formal secara efektif. Mengatasi masalah, refleksi, kreativitas, berpikir kritis, metakognisi, pengambilan risiko, komunikasi, kolaborasi, inovasi dan kewirausahaan menjadi kunci kompetensi untuk hidup dan bekerja pada abad dua puluh satu.

Dalam konteks pendidikan, kurikulum merupakan komponen penting bagi berlangsungnya program pendidikan dan pembelajaran. Kurikulum dijadikan sebagai pedoman bagi terselenggaranya kegiatan pembelajaran dalam rangka mencapai tujuan pendidikan tertentu. Kurikulum berisi seperangkat rencana yang mengatur tujuan, isi, dan bahan pelajaran serta cara pembelajarannya (Undang-Undang Republik Indonesia Nomor 20 Tahun 2003 tentang Sistem Pendidikan Nasional 2003). Definisi ini menyiratkan pentingnya kedudukan kurikulum sebagai acuan penyelenggaraan program pendidikan, dengan mengacu pada kurikulum ini seluruh sumberdaya pendidikan digerakkan untuk mencapai tujuan pendidikan.

Seperangkat tujuan pendidikan dalam kurikulum 2013 terumuskan dalam ranah kompetensi sikap, kompetensi pengetahuan, dan kompetensi ketrampilan. Ketiga ranah ini saling berkaitan satu dengan yang lainnya, dimana dalam proses pembelajarannya dicapai melalui pembelajaran langsung untuk mencapai ranah pengetahuan melalui aktivitas ranah ketrampilan. Selanjutnya dampak dari pembelajaran langsung ini akan terinternalisasi ranah sikap yang dikenal dengan nilai-nilai karakter. Berkaitan internalisasi nilainilai sikap, temuan penelitian (Graff, 2012) menunjukkan bahwa program pendidikan karakter berjalan sukses pada sekolah tingkat menengah dan atas, dan guru dapat secara efektif memasukkan nilai-nilai inti ke dalam kurikulum 
sekolah. Lickona (2001) mendefinisikan karakter secara komprehensif dengan memasukkan pemikiran (pengetahuan), perasaan, dan perilaku.

Namun demikian, hasil penelitian Wardoyo \& Mangifera (2016) terhadap mahasiswa berbagai perguruan tinggi di Jakarta, Bogor, Bandung, dan Surakarta menunjukkan kurikulum dan model pembelajaran tidak mendukung tumbuhnya intensi berwirausaha mahasiswa, padahal intensi berwirausaha mereka besar, sehingga hanya sebagian kecil saja mahasiswa yang memulai membuka usaha. Analisis Winarno (2009) terhadap naskah kurikulum mata pelajaran Kewirausahaan pada Kurikulum Tingkat Satuan Pendidikan (KTSP) menunjukkan sedikit sekali muatan pengembangan sikap kewirausahaan dan sebagian besar muatan kurikulum terkait dengan ketrampilan berbisnis. Bahkan penggunaan metode ceramah lebih dominan, sedangkan metode diskusi dan penugasan jarang digunakan. Implikasinya adalah sikap kewirausahaan siswa belum terbentuk dengan baik.

Demikian halnya proses pendidikan Kewirausahaan pada sekolah menengah kejuruan pada kurikulum 2013 dalam persektif guru dan sekolah ditemukan tidak ada perbedaan yang sigifikan dengan proses pendidikan Kewirausahaan pada era KTSP (Winarno 2015). Hal ini terjadi karena guru masih beradaptasi dengan silabus Kurikulum 2013 yang belum terstandar. Dalam prakteknya, para guru menilai prakarya yang diajarkan kurang relevan dengan bidang keahlian yang ditawarkan di sekolah. Lebih-lebih sekolah juga dihadapkan oleh minimnya fasilitas, dan rata-rata sekolah tidak menetapkan kebijakan khusus untuk mengimplementasikan mata pelajaran tersebut.

Hal demikian mungkin berbeda dengan muatan pada Kurikulum 2013 edisi revisi 2016 pada naskah kurikulum mata pelajaran Prakarya dan Kewirausahaan. Hal ini dapat terjadi, karena kurikulum edisi revisi merupakan kurikulum yang dikembangkan berdasar kelemahan-kelemahan pada kurikulum edisi sebelumnya. Pengkajian isi kurikulum kewirausahaan merupakan suatu hal yang penting, karena pendidikan kewirausahaan terbukti mampu untuk memotivasi para peserta didik untuk berani memulai bisnis start up. Pentingnya pendidikan Kewirausahaan untuk meningkatkan motivasi berwirausaha didukung temuan penelitian Aprilianty (2012) yang menunjukkan bahwa pengetahuan kewirausahaan dan kepribadian wirausaha berpengaruh positif signifikan terhadap minat berwirausaha. Ini berarti minat menjadi wirausaha dapat diprediksi dari penguasaan pengetahuan dan nilainilai kepribadian wirausaha yang dimiliki oleh para siswa. Hasil uji regresi Wahidmurni (2013) menunjukkan terdapat pengaruh simultan positif signifikan dari ketiga ranah hasil belajar (kognitif, afektif dan psikomotor) pendidikan kewirausahaan pada pembentukan watak wirausaha mahasiswa. Temuantemuan penelitian semacam ini memperkokoh pentingnya kehadiran mata pelajaran Kewirausahaan di sekolah.

Temuan penelitian lainnya, misalnya Seun et al. (2017) mengungkapkan pendidikan kewirausahaan berperan sebagai variabel moderator yang lebih tinggi terhadap motivasi (motif intrinsik dan ekstrinsik) berwirausaha mahasiswa. Motivasi berwirausaha berpengaruh positif signifikan terhadap kesiapan kearah bisnis start-up baru. Motif ekstrinsik memiliki pengaruh yang lebih tinggi untuk memulai bisnis start-up baru para mahasiswa, motif intrinsik juga penting untuk mendapatkan rezeki dari usaha bisnis baru. 
Pentingnya menumbuhkan motivasi untuk berwirausaha bagi siswa, didukung oleh temuan (Wahidmurni,2017) yang menunjukkan bahwa niat menjadi seorang pengusaha sangat dipengaruhi oleh kesadaran motif mencari keuntungan dan kebebasan berekspresi. Kesadaran ini tumbuh karena kemampuannya membaca dan memanfaatkan peluang bisnis, selanjutnya menjadikan pengusaha muda menjadi lebih inovatif dan mengilhaminya untuk memanfaatkan peluang bisnis yang ada. Dengan demikian, tantangannya adalah bagaimana mendesain kurikulum yang mampu menginternalisasikan nilai-nilai kewirausahaan yang mencakup sikap, pengetahuan, dan ketrampilan secara optimal pada diri peserta didik.

\section{METODE PENELITIAN}

Penelitian ini bertujuan untuk mengungkap kesenjangan yang terjadi antara serangkaian kompetensi yang ada pada naskah kurikulum matapelajaran Prakarya dan Kewirausahaan yang memuat kompetensi sikap, pengetahuan dan ketrampilan sebagai fenomena dengan naskah indikator ketercapaian nilai-nilai kewirausahaan sebagai kriteria. Kesenjangan antara nilai-nilai sikap yang tertuang pada naskah kegiatan pembelajaran dalam silabus yang dikembangkan oleh pemerintah sebagai fenomena dengan nilai-nilai sikap yang tertuang dalam naskah indikator ketercapaian nilai-nilai kewirausahaan sebagai kriteria.

Tabel 1. Indikator Ketercapaian Nilai-Nilai Kewirausahaan

\begin{tabular}{|c|c|c|}
\hline No. & $\begin{array}{c}\text { Nilai-Nilai } \\
\text { Kewirausahaan }\end{array}$ & Indikator Ketercapaian Individu \\
\hline 1. & Mandiri & $\begin{array}{l}\text { a. Melakukan sendiri tugas kelas yang menjadi kewajibannya } \\
\text { b. Tidak bergantung pada orang lain }\end{array}$ \\
\hline 2. & Kreatif & $\begin{array}{l}\text { a. Mengajukan pendapat yang berkaitan dengan tugas } \\
\text { pokoknya } \\
\text { b. Mengemukakan gagasan baru } \\
\text { c. Mendiskripsikan konsep dengan kata-kata sendiri }\end{array}$ \\
\hline 3. & $\begin{array}{l}\text { Berani mengambil } \\
\text { resiko }\end{array}$ & $\begin{array}{l}\text { a. Menyukai tugas yang menantang } \\
\text { b. Berani menerima akibat dari perbuatannya sendiri }\end{array}$ \\
\hline 4. & $\begin{array}{l}\text { Berorientasi pada } \\
\text { tindakan }\end{array}$ & $\begin{array}{l}\text { a. Mewujudkan gagasan dengan tindakan } \\
\text { b. Senang berbuat sesuatu }\end{array}$ \\
\hline 5. & Kepemimpinan & $\begin{array}{l}\text { a. Terbuka terhadap saran dan kritik } \\
\text { b. Bersikap sebagai pemimpin dalam kelompok } \\
\text { c. Membagi tugas dalam kelompok } \\
\text { d. Menjadi role model }\end{array}$ \\
\hline 6. & Kerja keras & $\begin{array}{l}\text { a. Mengerjakan tugas pada waktu yang telah ditentukan } \\
\text { b. Tidak putus asa dalam menghadapi kesulitan belajar } \\
\text { c. Selalu fokus pada pekerjaan atau pelajaran }\end{array}$ \\
\hline 7. & Konsep & Memahami konsep-konsep dasar kewirausahaan \\
\hline 8. & Skill/Ketrampilan & $\begin{array}{l}\text { a. Mampu mengidentifikasi peluang usaha } \\
\text { b. Mampu mengalisis secara sederhana peluang berserta } \\
\text { resikonya } \\
\text { c. Mampu merumuskan dan merancang usaha bisnis } \\
\text { d. Mampu berlatih membuka usaha baru secara berkelompok } \\
\text { atau individu dengan berorientasi pada profit }\end{array}$ \\
\hline
\end{tabular}


Nilai-nilai dari ciri-ciri seorang wirausaha yang dikembangkan oleh Pusat Kurikulum (2010) ke dalam indikator ketercapaian nilai-nilai kewirausahaan pada jenjang pendidikan menengah mengandung 6 nilai pokok dari 17 nilai pokok, dimana 11 nilai pokok sebelumnya ditargetkan dicapai pada jenjang pendidikan dasar. Keenam nilai pokok yang dimaksud adalah: (1) mandiri, (2) kreatif, (3) berani mengambil resiko, (4) berorientasi pada tindakan, (5) kepemimpinan, dan (6) kerja keras. Adapun kesebelas nilai pokok yang ditargetkan dicapai pada jenjang pendidikan dasar adalah: (1) jujur, (2) disiplin, (3) inovatif, (4) tanggung jawab, (5) kerja sama, (6) pantang menyerah (ulet), (7) komitmen, (8) realistis, (9) rasa ingin tahu, (10) komunikatif, dan (11) motivasi yang kuat untuk sukses.

Indikator ketercapaian nilai-nilai kewirausahaan yang ditetapkan sebagai kriteria dalam penelitian ini dikembangkan oleh Pusat Kurikulum Kementerian Pendidikan Nasional pada tahun 2010, tersaji dalam Tabel 1.

Pemetaan kesenjangan ini penting untuk diungkap sebagai bahan masukan untuk melakukan revisi kurikulum berikutnya. Untuk mencapai tujuan tersebut, digunakan metode penelitian evaluasi program dengan desain Goal Oriented Evalution Model, yang dikembangkan oleh Tyler (dalam Jaedun, 2010), yakni dengan menjadikan tujuan dari suatu program yang sudah ditetapkan sebelum program tersebut dimulai sebagai obyek penelitian. Langkah analisis mengikuti langkah analisis yang digunakan Youker et al. (2016) yakni, menetapkan dengan menetapkan kriteria, standar, pengukuran/observasi dan sintesis. Secara rinci langkah analisisnya adalah: (1) menetapkan kriteria, yakni mencakup ketepatan dalam merumuskan kata kerja ranah sikap, ranah pengetahuan, dan ranah ketrampilan; (2) standar yang digunakan adalah rumusan nilai-nilai dari ciri-ciri seorang wirausaha yang dikembangkan oleh Pusat Kurikulum tahun 2010 dan Standar Proses Pendidikan Dasar dan Menengah menurut Peraturan Menteri Pendidikan dan Kebudayaan Republik Indonesia Nomor 22 Tahun 2016 (3) pengukuran/ observasi dilakukan dengan cara memeriksa rumusan-rumusan kompetensi dan rumusan kegiatan yang terkait dengan kegiatan pembelajaran, dan membadingkannya dengan standar yang digunakan untuk penilaian, (4) sintesis dilakukan dengan memprofilkan setiap kriteria dan menarik satu kesimpulan evaluatif pada masing-masing kriteria.

\section{HASIL PENELITIAN DAN PEMBAHASAN}

Tujuan kurikulum mata pelajaran Prakarya dan Kewirausahaan di SMA/MA/SMK/MAK adalah membekali siswa agar memiliki kemampuan untuk membuat produk prakarya yang memiliki nilai jual pada skala dami, dengan cara memahami dan membandingkan berbagai desain karya, mengidentifikasi, dan mendeskripsikan proses pembuatan karya, membuat dan memodifikasi karya dalam konteks kearifan lokal secara detail dan bernilai jual. Arahnya pada pengembangan produk dengan menggunakan teknologi tepat guna skala home industry dengan wawasan kewirausahaan agar dapat mandiri secara ekonomi.

Pada naskah Kurikulum 2013 Edisi Revisi 2016 mata pelajaran ini dirancang untuk membekali peserta didik untuk memiliki sikap, pengetahuan 
dan ketrampilan yang berkaitan dengan kemampuan mengembangkan produk yang bermanfaat dan memiliki nilai ekonomis. Selanjutnya ketiga aspek dikembangkan dalam silabus dengan rincian berikut:

\section{Indikator Ketercapaian Nilai-nilai Kewirausahaan dari Aspek Sikap}

Kompetensi inti sikap Kurikulum 13 dirumuskan dalam dua katagori, yakni (1) sikap spiritual dengan rumusan menghargai dan menghayati ajaran agama yang dianutnya, dan (2) sikap sosial dengan rumusan menghargai dan menghayati perilaku jujur, disiplin, tanggungjawab, peduli (toleransi, gotong royong), santun, percaya diri, dalam berinteraksi secara efektif dengan lingkungan sosial dan alam dalam jangkauan pergaulan dan keberadaannya (Kemendikbud,2016). Rumusan lain yang terdapat dalam naskah kurikulum adalah sikap kreatif, rasa kepedulian, ingin tahu, rasa keindahan, cekatan, ekonomis dan praktis. Dengan demikian terdapat dua belas rumusan sikap sosial yang dicapai dalam pembelajaran.

Rumusan nilai-nilai dari ciri-ciri seorang wirausaha yang dikembangkan oleh Pusat Kurikulum (2010) yang hendak dicapai oleh peserta didik setelah menempuh mata pelajaran Prakarya dan Kewirausahaan pada jenjang pendidikan menengah adalah: (1) mandiri, (2) kreatif, (3) berani mengambil resiko, (4) berorientasi pada tindakan, (5) kepemimpinan, dan (6) kerja keras. Dari keenam rumusan tersebut hanya satu rumusan yang ditemukan dalam keduabelas rumusan sikap sosial yang tertulis pada naskah silabus mata pelajaran Prakarya dan Kewirausahaan, yakni sikap kreatif (Kemendikbud, 2016). Untuk itu perlu memasukkan nilai-nilai wirausaha secara tersirat dalam rumusan sikap dalam naskah kurikulum beserta silabusnya. Lebih-lebih jika nilai-nilai wirausaha dijadikan landasan dalam praktek pendidikan dan pembelajaran di sekolah.

Nilai-nilai kepribadian wirausaha penting lainnya mungkin perlu digali

dan dipertimbangkan dalam pengembangan kurikulum. Nilai-nilai kepribadaian tersebut adalah toleran terhadap risiko dan ketidakpastian, memiliki visi, kapasitas memberi inspirasi, kreativitas, pengendalian diri, kepercayaan diri, energi/semangat tinggi, pengawasan internal yang tegas, tabah dan gigih, proaktif, terdorong mandiri, fleksibel, kemampuan belajar, komitmen terhadap sesama (Sapir et al., 2014).

Welsh, D.H.B., \& Drăguşin (2011) menyimpulkan bahwa tidak terdapat konsensus tentang apa dan bagaimana cara terbaik dalam membelajarkan kewirausahaan, tetapi secara umum diterima bahwa konten dan pedagogik seharusnya menargetkan tiga karakteristik utama dari seorang pengusaha dan inovator, yakni pengetahuan, ketrampilan dan sikap. Hal demikian sesungguhnya sudah menjadi pertimbangan dalam merumuskan tujuan dari setiap mata pelajaran dalam kurikulum, yakni adanya tiga ranah/domain yang dicapai, yakni ranah sikap, ranah pengetahuan dan ranah ketrampilan. Hanya saja praktik pembelajarannya seringkali yang kurang sesuai dengan tujuan yang diharapkan. Sebagai contoh temuan penelitian Winarno (2009) terhadap proses pembelajaran kewirausahaan di SMK menunjukkan bahwa metode pembelajaran yang sering digunakan adalah metode ceramah, di samping metode penugasan untuk menjual produk dan kegiatan pengamatan sesekali waktu digunakan karena terbatasnya waktu pembelajaran. 
Sesuai dengan karakteristik sikap, maka salah satu alternatif yang dipilih adalah proses afeksi mulai dari menerima, menjalankan, menghargai, menghayati, hingga mengamalkan. Seluruh aktivitas pembelajaran berorientasi pada tahapan kompetensi yang mendorong peserta didik untuk melakukan aktivitas tersebut. Untuk itu saran King et al. (1997) perlu dipertimbangkan, bahwa pembelajaran kooperatif dan kegiatannya melibatkan tugas-tugas yang menantang, ternyata efektif meningkatkan ketrampilan berpikir. Aktivitasnya dapat berupa diskusi kelompok, bimbingan teman sejawat, dan umpan balik diberikan secara langsung, spesifik dan korektif. Strategi pembelajaran dan lingkungan belajar yang tepat dapat memfasilitasi pertumbuhan peserta didik dalam hal ketekunan, intropeksi diri, sikap terbuka, dan fleksibel. Ini berarti bahwa, pemilihan strategi, metode dan teknik pembelajaran yang tepat oleh guru dalam melaksanakan pembelajaran langsung; dapat berdampak pada tercapainya nilai-nilai sikap wirausaha.

Tiga tahapan model pembelajaran Kewirausahaan yang ditawarkan Sapir et al. (2014) adalah: (1) menanamkan nilai sosial dan nilai kepribadian individu wirausaha, (2) menginternalisasikannya dalam aksi dan tindakan berwirausaha, dan (3) mewujudkan perilaku tindak nyata berwirausaha ke dalam (intrapreneurship) dan ke luar perusahaan (entrepreneurship). Namun demikian, hal terpenting adalah peran semua staf sekolah (guru, karyawan dan pihak manajemen) dalam menanamkan nilai-nilai wirausaha, atau setidaknya ada model dari sebagian staf sekolah yang menjadi wirausaha sukses untuk menjadi model bagi para siswa. Hal ini sebagaimana di ungkapkan Lickona (2001) bahwa tanggung jawab untuk pemodelan dan mempromosikan karakter adalah seluruh staf sekolah.

Saran-saran tersebut sebenarnya sudah dirumuskan dengan baik dalam Kurikulum 13 bahwa, kompetensi sikap spiritual dan sosial diinternalisasikan kepada peserta didik melalui pembelajaran tidak langsung (indirect teaching) yaitu keteladanan, pembiasaan, dan budaya sekolah, juga melalui kegiatan pembelajaran. Untuk itu, pendekatan saintifik dirumuskan dalam setiap kegiatan pembelajaran dalam silabus mata pelajaran, dan model-model pembelajaran yang direkomendasikan untuk digunakan adalah pembelajaran berbasis masalah, pembelajaran berbasis proyek, pembelajaran penemuan dan penyelidikan, dan pembelajaran kooperatif. Hanya saja dalam prakteknya masih perlu upaya perbaikan terus menerus, sebagaimana temuan Winarno (2009) adanya kekurangtepatan dalam menerapkan metode pembelajaran dalam pembelajaran Kewirausahaan.

\section{Indikator Ketercapaian Nilai-nilai Kewirausahaan dari Aspek Pengetahuan}

Rumusan kompetensi dasar aspek pengetahuan dalam naskah kurikulum mata pelajaran Prakarya dan Kewirausahaan di kelas X, XI, dan XII dalam aspek kerajinan, rekayasa, budidaya, dan pengolahan dapat diringkas dalam Tabel 2.

Materi pokok yang dikaji dalam mata pelajaran Prakarya dan Kewirausahaan pada setiap kelasnya adalah sama, yakni mencakup: perencanaan usaha, sistem produksi, perhitungan biaya produksi, pemasaran, dan proses evaluasi kegiatan usaha, kecuali untuk di kelas X diperkenalkan 
materi pokok karakteristik kewirausahaan. Perbedaan hanya terdapat pada isi dari aspek jenis kerajinan prakarya yang dipelajari, yakni: kerajinan dengan inspirasi budaya lokal non benda dan kerajinan dengan inspirasi artefak/objek budaya lokal untuk kelas X; kerajinan dari bahan limbah bahan kertas dan kerajinan dari bahan limbah berbentuk bangun ruang untuk kelas XI, dan kerajinan yang berdasarkan pada kebutuhan dan keinginan lingkungan sekitar/pasar lokal, dan kerajinan berdasarkan pada kebutuhan dan keinginan pasar global untuk kelas XII.

Tabel 2. Kompetensi Aspek Pengetahuan

\section{Konsep/Pengetahuan}

Kompetensi pengetahuan yang terumus di kelas X, XI, dan XII:

1. Memahami karakteristik kewirausahaan

2. Memahami perencanaan usaha

3. Memahami/menganalisis sistem produksi

4. Memahami perhitungan biaya produksi (Harga Pokok Produksi/HPP)

5. Memahami pemasaran

6. Memahami/menganalisis proses evaluasi kegiatan usaha

7. Memahami perencanaan usaha

8. Memahami/menganalisis sistem produksi

9. Memahami perhitungan biaya produksi (Harga Pokok Produksi)

10. Memahami cara pemasaran

11. Memahami/menganalisis proses evaluasi hasil kegiatan usaha

Ada dua belas silabus yang dirumuskan dalam naskah kurikulum, masing-masing kelas terdiri atas 4 aspek yakni kerajinan, rekayasa, budidaya, dan pengolahan, hal ini yang menyebabkan terjadinya rumusan kata kerja berbeda dalam kompetensi pada materi pokok yang sama. Misalnya dalam materi pokok sistem produksi, tertulis rumusan kompetensi dasarnya memahami sistem produksi dan menganalisis sistem produksi. Demikian juga rumusan kompetensi dasar dengan materi pokok evaluasi hasil kegiatan usaha, terdapat dua rumusan yang berbeda yakni memahami menganalisis proses evaluasi hasil kegiatan usaha dan menganalisis proses evaluasi hasil kegiatan usaha.

Aspek/ranah pengetahuan yang harus dikuasai peserta didik terdiri atas enam tingkatan yakni: mengingat, memahami, menerapkan, menganalisis, mengevaluasi, hingga mencipta/mengkreasi. Aktivitas ini mencerminkan ranah berpikir dari taxonomi Bloom yang direvisi Lorin Anderson dan David Krathwohl dan secara eksplisit digunakan sebagai capaian pembelajaran dalam ranah kognitif dalam kurikulum 2013 (Permendikbud No. 22/2016). Aktivitas berpikir tersusun secara hirarkis, dan umumnya dikenal dengan istilah cognitive 1 (C1) sampai dengan cognitive 6 (C6). Susunan hirarkisnya, C1 untuk mengingat (remembering), $\mathrm{C} 2$ untuk memahami (understanding), C3 untuk menerapkan (applying), C4 untuk menganalisis (analyzing), C5 menilai (evaluating), dan C6 untuk mengkreasi (creating).

Hasil analisis menunjukkan bahwa sebagaian besar rumusan kata kerja kompetensi dasar menggunakan kata memahami (C2) dan pada materi yang sama juga tertulis kata menganalisis (C4) pada kasus (1) memahami/ menganalisis sistem produksi, dan (2) memahami/menganalisis proses evaluasi Pelajaran Prakarya dan Kewirausahaan Jenjang Pendidikan Menengah 
hasil kegiatan usaha. Hal ini menunjukkan tidak adanya konsistensi penulisan kata kerja dalam kompetensi dasar yang sama. Pemilihan kata kerja yang digunakan dalam merumuskan kompetesi dasar merupakan hal yang sangat penting, karena rumusan kata kerja kompetensi dasar akan menentukan kata kerja operasional dalam merumuskan indikator pencapaian kompetensi, mempengaruhi ruang lingkup materi yang akan dikembangkan, dan jenis penilaian yang akan digunakan. Saran perbaikan untuk rumusan kata kerja kompetensi dasar ranah kognitif tersaji pada tabel 3.

Tabel 3. Usulan Perubahan Rumusan Kata Kerja KD Pengetahuan

\begin{tabular}{ll}
\hline \multicolumn{1}{c}{ Rumusan Semula } & \multicolumn{1}{c}{ Rumusan Perubahan } \\
\hline $\begin{array}{l}\text { Memahami karakteristik kewirausahaan } \\
(\mathrm{C} 2)\end{array}$ & Tetap \\
\hline Memahami perencanaan usaha (C2) & Menyusun perencanaan usaha (C6) \\
\hline $\begin{array}{l}\text { Memahami/menganalisis sistem produksi } \\
(\mathrm{C} 2 / \mathrm{C} 4)\end{array}$ & Menganalisis sistem produksi (C4) \\
\hline Memahami perhitungan HPP (C2) & $\begin{array}{l}\text { Menerapkan perhitungan HPP } \\
(\mathrm{C} 3)\end{array}$ \\
\hline Memahami pemasaran (C2) & $\begin{array}{l}\text { Menganalis strategi pemasaran } \\
(\mathrm{C} 4)\end{array}$ \\
\hline $\begin{array}{l}\text { Memahami/menganalisis proses evaluasi } \\
\text { kegiatan usaha (C2/C4) }\end{array}$ & Mengevaluasi kegiatan usaha (C5) \\
\hline
\end{tabular}

Berdasarkan usulan di atas, maka ciri berpikir tingkat tinggi atau higher order thinking skills (HOTS) sudah terpenuhi, yakni dengan adanya kata kerja ranah kognitif tingkat 4, 5 dan 6. Krathwohl (2002) menyimpulkan taksonomi asli terdiri dari enam kategori, disusun dalam kerangka hirarkis kumulatif; pencapaian berikutnya adalah keterampilan atau kemampuan yang lebih kompleks, memerlukan pencapaian prestasi sebelumnya. King et al. (1997) menyatakan HOTS melibatkan ketrampilan berpikir kritis, logis, reflektif, metakognitif, dan kreatif. Ketrampilan ini dapat diperoleh peserta didik, jika mereka dihadapkan pada masalah, ketidakpastian, pertanyaan-pertanyaan, dan dilema.

Perolehan pengetahuan melalui aktivitas berpikir tingkat tinggi merupakan salah satu cara untuk menginternalisasikan nilai-nilai wirausaha, sebab kemampuan berpikir tingkat tinggi membutuhkan kemampuan berpikir yang kreatif dan kerja keras. Kemampuan berpikir kreatif dan kerja keras diperlukan peserta didik yang dihadapkan pada tantangan untuk memecahkan masalah pembelajaran dengan berbagai alternatif pemecahan.

\section{Indikator Ketercapaian Nilai-nilai Kewirausahaan dari Aspek Ketrampilan}

Rumusan kompetensi dasar aspek ketrampilan dalam naskah kurikulum mata pelajaran Prakarya dan Kewirausahaan di kelas X, XI, dan XII dalam aspek kerajinan, rekayasa, budidaya, dan pengolahan dapat diringkas dalam Tabel 4. 
Tabel 4. Kompetensi Aspek Ketrampilan

\begin{tabular}{l}
\hline \multicolumn{1}{c}{ Skill/Ketrampilan } \\
\hline Kompetensi ketrampilan yang terumus di kelas X, XI, dan XII: \\
\hline Mengidentifikasi karakteristik wirausahawan berdasarkan keberhasilan dan \\
kegagalan usaha \\
\hline Menyusun perencanaan usaha \\
\hline Memproduksi kerajinan \\
\hline Menghitung biaya produksi (HPP) \\
\hline Memasarkan produk \\
\hline Mengevaluasi hasil kegiatan usaha \\
\hline Menyusun perencanaan usaha administrasi dan pemasaran \\
\hline Merumuduksi kerajinan kerajinan \\
\hline Memasil perhitungan biaya produksi (Harga Pokok Produksi) \\
\hline Mengevaluasi hasil kegiatan usaha \\
\hline
\end{tabular}

Rumusan kompetensi dasar aspek ketrampilan menggunakan kata kerja mengidentifikasi, menyusun, memproduksi, menghitung, memasarkan, dan mengevaluasi; padahal ranah keterampilan dalam Kurikulum 2013 diperoleh melalui kegiatan mengamati, menanya, mencoba, menalar, menyaji, dan mencipta. Seluruh isi materi (topik dan sub topik) mata pelajaran yang diturunkan dari keterampilan harus mendorong peserta didik untuk melakukan proses pengamatan hingga penciptaan (Peraturan Menteri Pendidikan dan Kebudayaan Republik Indonesia Nomor 22 Tahun 2016 Tentang Standar Proses Pendidikan Dasar dan Menengah). Dengan demikian rumusan kata kerja dalam kompetensi dasar ini harus disesuaikan, sebab kata kerja mengidentifikasi, menyusun, menghitung, mengevaluasi merupakan kata kerja kompetensi dasar ranah kognitif.

Aspek ketrampilan dalam kurikulum 2013 terbagi atas dua ketrampilan yakni ketrampilan abstrak, terdiri atas ketrampilan mengamati, menanya, mencoba, menalar, menyaji, mencipta; dan ketrampilan kongkrit dengan mengadopsi aspek psikomotor taxonomy Bloom's terdiri atas perception, set, guided response, mechanism, complex overt response (expert), adaptation, and origination. Saran perbaikan untuk rumusan kata kerja kompetensi dasar ranah ketrampilan tersaji pada Tabel 5.

Tabel 5. Usulan Perubahan Rumusan Kata Kerja KD Ketrampilan

\begin{tabular}{ll}
\hline \multicolumn{1}{c}{ Rumusan Semula } & \multicolumn{1}{c}{ Rumusan Usulan } \\
\hline $\begin{array}{l}\text { Mengidentifikasi karakteristik } \\
\text { wirausahawan berdasarkan } \\
\text { keberhasilan dan kegagalan usaha }\end{array}$ & $\begin{array}{l}\text { Menyajikan karakteristik wirausahawan } \\
\text { berdasarkan keberhasilan dan kegagalan } \\
\text { usaha }\end{array}$ \\
\hline Menyusun perencanaan usaha & Menyajikan proposal perencanaan usaha \\
\hline Memproduksi kerajinan & Menciptakan/memproduksi kerajinan \\
\hline Menghitung biaya produksi & Menyajikan perhitungan biaya produksi \\
\hline Memasarkan produk & Memasarkan produk \\
\hline Mengevaluasi hasil kegiatan usaha & Menyajikan evaluasi hasil kegiatan usaha \\
\hline
\end{tabular}

Dalam kurikulum 2013, ketrampilan-ketrampilan tersebut kecuali ketrampilan menciptakan kerajinan dan memasarkan produk karena bersifat 
kongkrit dapat dicapai melalui aktivitas belajar secara langsung dengan menggunakan model-model pembelajaran sebagaimana direkomendasikan seperti: pembelajaran berbasis masalah, pembelajaran berbasis proyek, pembelajaran penemuan dan penyelidikan, dan pembelajaran kooperatif.

Dalam proses pembelajaran dalam Kurikulum 13, peserta didik belajar dengan cara terlibat dalam proses mengamati, menanya, mengumpulkan informasi (mencoba), menalar (mengasosiasi), dan mengkomunikasikan yang katagorikan sebagai ranah ketrampilan abstrak untuk mendapatkan pengetahuan. Keseluruhan proses ini dalam kurikulum 2013 dikenal dengan istilah pendekatan saintifik. Melalui proses belajar tersebut, diharapkan internalisasi beragam nilai-nilai sikap dapat dicapai.

Untuk itu, pencapaian seluruh kompetensi kewirausahaan dari aspek sikap, pengetahuan dan ketrampilan dapat dicapai melalui perancangan skenario kegiatan pembelajaran langsung, dan sekaligus memikirkan efek tidak langsungnya pada pembentukan sikap peserta didik. Rekomendasi penggunanaan model-model pembelajaran seperti pembelajaran kooperatif, pembelajaran penemuan dan penyelidikan, pembelajaran berbasis proyek, dan pembelajaran berbasis masalah dalam Kurikulum 2013 sudah tepat untuk mencapai kompetensi yang diharapkan. Hal ini sebagaimana dinyatakan oleh Scott (2015) bahwa pembelajaran di era digital, pendidik harus menyusun skenario yang memberikan pengalaman peserta didik berkolaborasi memecahkan masalah yang kompleks, seringkali tidak jelas dan mencakup banyak aspek. Pendidik memberi kesempatan kepada mereka untuk merefleksikan ide, melakukan analisis, berpikir kritis dan kreatif, menunjukkan inisiatif. Wagner (2010) menekankan pentingnya kegiatan pembelajaran dirancang untuk mencapai tujuh keterampilan untuk kehidupan abad ke dua puluh satu, yakni: berpikir kritis dan pemecahan masalah, kolaborasi dan kepemimpinan, kelincahan dan kemampuan beradaptasi, inisiatif dan kewirausahaan, komunikasi lisan dan tertulis yang efektif, mengakses dan menganalisis informasi, keingintahuan dan imajinasi.

Model-model pembelajaran yang direkomendasikan, jika dilaksanakan secara konsisten akan mampu menginternalisasikan nilai-nilai sikap, pengetahuan dan ketrampilan kewirausahaan secara optimal pada diri peserta didik. Penerapan model pembelajaran yang direkomendasikan memberikan pengalaman kepada siswa untuk terampil bekerja sama mencari pengetahuan, dengan cara mengalami mulai dari mengamati sampai pada aktivitas mengkomunikasikan pengetahuan dan produk prakarya yang dihasilkan kepada pihak lain. Proses pembelajaran yang dialami secara tidak langsung akan menginternalisasi nilai-nilai kewirausahaan pada diri siswa.

\section{SIMPULAN}

Enam buah nilai dari ciri-ciri seorang wirausaha yakni: mandiri, kreatif, berani mengambil resiko, berorientasi pada tindakan, kepemimpinan, dan kerja keras yang akan diinternalisasikan dalam kegiatan pembelajaran, hanya terumuskan satu nilai dalam naskah kurikulum mata pelajaran Prakarya dan Kewirausahaan, yakni nilai kreatif. Ketiadaan rumusan nilai yang lain, akan sangat memungkinkan nilai-nilai tersebut tidak terinternalisasi dalam diri 
siswa. Hal ini dapat terjadi karena silabus yang telah dikembangkan dari pusat kurikulum akan menjadi acuan utama guru dalam mengembangkan program pembelajarannya.

Semua rumusan kata kerja kompetensi ranah kognitif dalam naskah kurikulum mata pelajaran Prakarya dan Kewirausahaan adalah memahami (C2) dari taxonomy Bloom, meskipun ditemukan juga kata kerja menganalisis (C4) namun kata kerja ini tidak konsisten digunakan pada semua kelas. Ketepatan penggunaan kata kerja kompetensi dasar memahami hanya sesuai untuk kompetensi dasar yang pertama di kelas X, ketika pertemuan pertama mata pelajaran dengan tujuan memberikan pemahaman kepada siswa tentang karakteristik kewirausahaan. Sedangkan untuk pertemuan berikutnya di kelas $\mathrm{X}$, XI, dan XII kata kerja memahami tidak tepat digunakan karena kompetensi yang diharapkan dari siswa adalah menyusun perencanaan usaha, memproduksi kerajinan, menerapkan perhitungan biaya produksi, menganalisis strategi pemasaran produk, dan mengevaluasi hasil kegiatan usaha.

Sebagian rumusan kata kerja kompetensi ranah ketrampilan menggunakan kata kerja kompetensi ranah kognitif seperti mengidentifikasi, menghitung dan mengevaluasi. Seharusnya kata kerja kompetensi ranah ketrampilan merujuk pada aktivitas belajar yang harus dialami siswa, mulai dari mengamati hingga mengkomunikasikan dan menciptakan. Kata yang tepat digunakan adalah menyajikan (secara lisan dan/atau secara tulisan dan/atau bentuk lainnya) sebagai wujud kemampuan siswa untuk mengkomunikasikan hasil belajarnya untuk ranah ketrampilan absrak, dan membuat/memproduksi untuk ranah ketrampilan kongkrit.

\section{DAFTAR RUJUKAN}

Aprilianty, E. 2012. "Pengaruh Kepribadian Wirausaha, Pengetahuan Kewirausahaan, dan Lingkungan terhadap Minat Berwirausaha Siswa SMK." Jurnal Pendidikan Vokasi 2 (3): 311-24. https://doi.org/https://doi.org/10.21831/jpv.v2i3.1039.

Graff, C. E. 2012. "The Effectiveness of Character Education Programs in Middle and High Schools"."

Jaedun, A. 2010. "Metode Penelitian Evaluasi Program." Yogyakarta. http://staffnew.uny.ac.id/upload/131569339/pengabdian/penelitianevaluasi-program.pdf.

Kemendikbud. 2016. Silabus Mata Pelajaran Prakarya dan Kewirausahaan Sekolah Menengah Atas/Madrasah Aliyah/Sekolah Menengah Kejuruan/Madrasah Aliyah Kejuruan (SMA/MA/SMK/MAK). Indonesia.

King, F. J., Goodson, L. \& Rohani, F. 1997. "Higher Order Thinking Skills: Definition, Teaching Strategies, Assessment." https://informationtips.files.wordpress.com/2016/02/higher-orderthinking-skills_.pdf. 
Krathwohl, David R. 2002. “A Revision of Bloom's Taxonomy: An Overview, Theory Into Practice." Theory into Practice. https://doi.org/10.1207/s15430421tip4104_2.

Lickona, T. 2001. "What is Effective Character Education." https://athenaeum.edu/pdf/What is Effective Character Education.pdf,.

Peraturan Menteri Pendidikan dan Kebudayaan Republik Indonesia Nomor 22 Tahun 2016 Tentang Standar Proses Pendidikan Dasar dan Menengah.

Pusat Kurikulum. 2010. "Bahan Pelatihan Penguatan Metodologi Pembelajaran Berdasarkan Nilai-Nilai Budaya untuk Membentuk Daya Saing dan Karakter Bangsa, Pengembangan Pendidikan Kewirausahaan.” Jakarta.

Sapir., Pratikto, H., Wasiti \& Hermawan, A. 2014. "Model Pembelajaran Kewirausahaan Berbasis Kearifan Lokal untuk Penguatan Ekonomi." Jurnal Pendidikan Dan Pembelajaran 21 (1): 79-91.

Scott, Cynthia Luna. 2015. "Education Research and Foresight the Futures of Learning 3: What Kind of Pedagogies for the 21st Century?" Educational Research and Foresight UNESCO.

Seun, A. O., A. W. Kalsom, A. Bilkis, and A. I. Raheem. 2017. "What Motivates Youth Enterprenuership? Born or Made." Pertanika Journal of Social Sciences and Humanities 25 (3): 1419-1428.

Undang-Undang Republik Indonesia Nomor 20 Tahun 2003 tentang Sistem Pendidikan Nasional. 2003.

UNESCO. 2008. "Final Report: Inter-Regional Seminar on Promoting Entrepreneurship Education in Secondary Schools." Thailand: 11-15 February.

Wagner, T. 2010. "Overcoming the Global Achievement Gap. Cambridge, Mass."

Wahidmurni. 2013. "Kontribusi Pendidikan Kewirausahaan pada Pembentukan Watak Wirausaha Mahasiswa.” Jurnal Ekonomi Bisnis 18 (1): 81-88.

. 2017. "Overcoming Business Obstacles: A Case Study of Young Entrepreneurs in Malang." Pertanika J. Soc. Sci. \& Hum 25 (5): 145154.

Wardoyo \& Mangifera, L. 2016. "Pendidikan Kewirausahaan di Perguruan Tinggi Antara Harapan dan Kenyataan.” Dalam Seminar Nasional dan Call for Papers RIEE, "Strategi Pembelajaran Kewirausahaan untuk 
Membentuk Wirausaha Tangguh dan Berdaya Saing Tinggi," edited by N. Heri Pratikto, H., Sudarmiatin; Sutrisno; Murwani, F.X. D., dan Restuningdyah, 81-93. Malang: Fakultas Ekonomi Universitas Negeri Malang, Malang. https://docplayer.info/29879177-Prosiding-seminarnasional-dan-call-for-papers-roundtable-for-indonesian-entrepreneurshipeducators-riee-2016.html.

Welsh, D.H.B., \& Drăguşin, M. 2011. "Entrepreneurship Education in Higher Education Institutions as A Requirement in Building Excellence in Business: The Case of The University of North Carolina at Greensboro." On International Society of Commodity Science and Technology 1: 26672 .

Winarno, A. 2009. "Pengembangan Model Pembelajaran Internalisasi NilaiNilai Kewirausahaan pada Sekolah Menengah Kejuruan di Kota Malang." Jurnal Ekonomi Bisnis 14 (2): 124-31.

Winarno, A. 2015. "Pendidikan Kewirausahaan SMK dengan K-13: Persepektif Guru Dan Sekolah.” http://fe.unp.ac.id/.

Youker, Brandon W, Alayna Zielinski, Ouen C Hunter, and Nicholas Bayer. 2016. "Who Needs Goals? A Case Study of Goal-Free Evaluation." Journal of MultiDisciplinary Evaluation 12 (27): 27-43. 